\title{
IMPACT OF ROAD DUALIZATION ON RESIDENTS OF OGBOMOSHO, OYO STATE, NIGERIA FOR SUSTAINABLE URBAN DEVELOPMENT
}

\author{
Afolabi Monisola TUNDE* \\ Department of Geography and Environmental Management, University of Ilorin, Nigeria, \\ e-mail: folamoni70@yahoo.com \\ Opeyemi Ruth BAMIKOLE \\ Department of Geography and Environmental Management, University of Ilorin, Nigeria, \\ e-mail: adeyemoruth2018@gmail.com
}

\begin{abstract}
Road development enhances easy movement of people and vehicles. This paper aims at determining the impact of road dualization on residents of Ogbomosho town in Oyo State, Nigeria for sustainable urban development. Specifically, it examines the sociodemographic characteristics of the respondents ; identify factors that necessitate the need for road dualization; evaluates the perception of the residents on the effect of the dualization of road on them ; and evaluates the facilities provided through road dualization project in the study area. Both primary and secondary sources of information were employed to collect data. Systematic random sampling technique was employed to select a total of 400 house hold heads. Tables, frequency counts, simple percentages and mean scores wereused to analyze the gathered data. Likert scale was also used in scaling the perceive deffects of road dualization on the residents. Findings revealed that increase in number of vehicles whichled to traffic congestion is the main factor for road dualization. Hence, demolition of buildings for road expansion has led to increase in cost of shops and living house rentage, air, noise and water pollution and reduction of socio-cultural ties. Road dualization has however provided improved transportation network $(\mathrm{x}=3.86)$ and provision of street light $(\mathrm{x}=3.81)$ which has led to reduction in traffic congestion and lighting of the area in the night. Recommendations made include development of strategies by the government towards achieving comprehensive and more acceptable road dualization project. Public relation activities should be brought for wardin to urban and regional planning.
\end{abstract}

Key words: Residents, road dualization, road transportation, urban development and urban renewal

$$
\text { * } * * * * * *
$$

\section{INTRODUCTION}

The spatial effects of landuse and transport planning on urban development have attracted the attention of urban planners. This is tied to rapid population growth and urban sprawl in most developing countries including Nigeria. According to Oyesiku (2011), infrastructural innovation and sustainable urban practice have become more difficult because most urban centers in Nigeria were planned before the establishment of regional town planning. Nigeria as a developing country is faced with a lot of problems such as rapid urbanization, poor infrastructure and ever increasing 
urban slums (Gbadegesin and Aluko 2010). Hence, the built environment in the country is fast degenerating. Osuide and Dimuna (2005) observed that the urbanization process in Nigeria is not accompanied with a corresponding supply of adequate infrastructure, houses and basic amenities. The Draft National Urban Development Policy (NUDP, 2004) noted that Nigeria towns are growing without adequate planning. Most buildings in the urban built environment are noncompliance with building bye-laws and regulations. These problems are however manifested physically, economically and socially. Physically, deteriorating urban areas exhibit poor sanitation, accumulation of refuse, effluent discharges and dust among others. From the economic perspectives, Nigerian cities are growing in population whereas the urban economic base of those cities is weak and declining. The concomitant development of urban sprawl on the fringes of any city has compounded the problem of unplanned residential neighborhoods which tend to destroy the scenic beauty of the city. From the social perspectives, urban decay deals with very high economic situations leading to prevalence of diseases, prostitution, high crime rates and violence among others. All these problems make city life insecure, thus forcing residents to flee from the city center to the fringes and countryside. In order to solve some of these problems, road dualization becomes very important. Hence, this study focuses on determining the impact of road dualization on residents of Ogbomosho, Oyo State, Nigeria. The study specifically examines the socio-demographic characteristics of the respondents; identifies factors that necessitate the need for road dualization; evaluates the perception of the affected residents on the effect of the dualization of road on them; and assesses the facilities provided through road dualization project in the study area.

\section{Urban Development Policy and Sustainability}

Mobility as well as transportation remain two important features in most Nigerian cities. Most cities in Nigeria are confronted by serious traffic congestion. To ensure good urban development that will be sustainable, easy movement of goods and people should be given priority in urban policy. In the urban development process, values, qualities and other attributes of the urban centers should be put into consideration so as to ensure sustainable development in the urban areas. Furthermore, city's identity, environmental, social and cultural concerns must be given special attention in the process of urban development (Herman, 2009a, b; Herman et al., 2017, 2018; Ilieș et al., 2013).Urban redevelopment such as road dualization means social and technical partnership based on the unification of the vision of politicians and designers. It is thus a multifaceted and complex process which should not be viewed merely as a physical and financial proposition, but as sociological, cultural, economical and political matter (Couch, 1990). According to Layard et al., (2012), town planning is the development of a local life, a regional character, a civic spirit, a unique individuality capable of improvement and development in many ways. Hence, the fundamental prerequisite to the success of any development is the complete integration of these programs with the general plan of the urban area (Miller, 1959).

\section{The Study Area}

The study area of this research work is Ogbomoso which is one of the urban centers in Oyo State. Ogbomoso is located between latitude $8^{\circ} 8^{\prime} 0^{\prime \prime}$ North of the equator and longitude $4^{\circ} 16^{\prime} 0^{\prime \prime}$ East of the Greenwich meridian (figure 1). It is $140 \mathrm{~km}$ North East of Ibadan, $58 \mathrm{~km}$ North West of Osogbo, $57 \mathrm{~km}$ South West of Ilorin and $53 \mathrm{~km}$ North East of Oyo (Oyo State Ministry of Land and Survey, 2016). It is located on the high way connecting North and South of Nigeria on the West flank (Adetunji et al., 2018). Ogbomosho is the second largest city in Oyo State and the $12^{\text {th }}$ largest city in Nigeria (Kabiru et al., 2014). Ogbomoso has a tropical climate. In winter, there is much less rainfall than in summer. The average annual temperature in Ogbomoso is $26.2{ }^{\circ} \mathrm{C}$ while average annual rainfall is $1216 \mathrm{~mm}$. ${ }^{1}$ The rainfall ranges between 1000 and 1500 millimeters. The

${ }^{1}$ http://en.climatedata.org/location/399286/ 
relative humidity is $60 \%$ on the average and the mean annual temperature range is wider about $5^{\circ} \mathrm{C}$ (Kuponiyi et al., 2010). As a matter of fact, Ogbomoso town forms part of the Western upland of Nigeria. It has an elevation of about 600 meters above sea level. The relief of the area is moderate with low forested hills but occasionally very steep sided ridges rise abruptly from the surrounding country. The main water shed is located at about $20 \mathrm{~km}$ North and $10 \mathrm{~km}$ East of Ogbomoso. South west of this water shed is "Oras" river with its tributaries flowing southwards and runs only west of Ogbomoso (Adetunji et al., 2018).

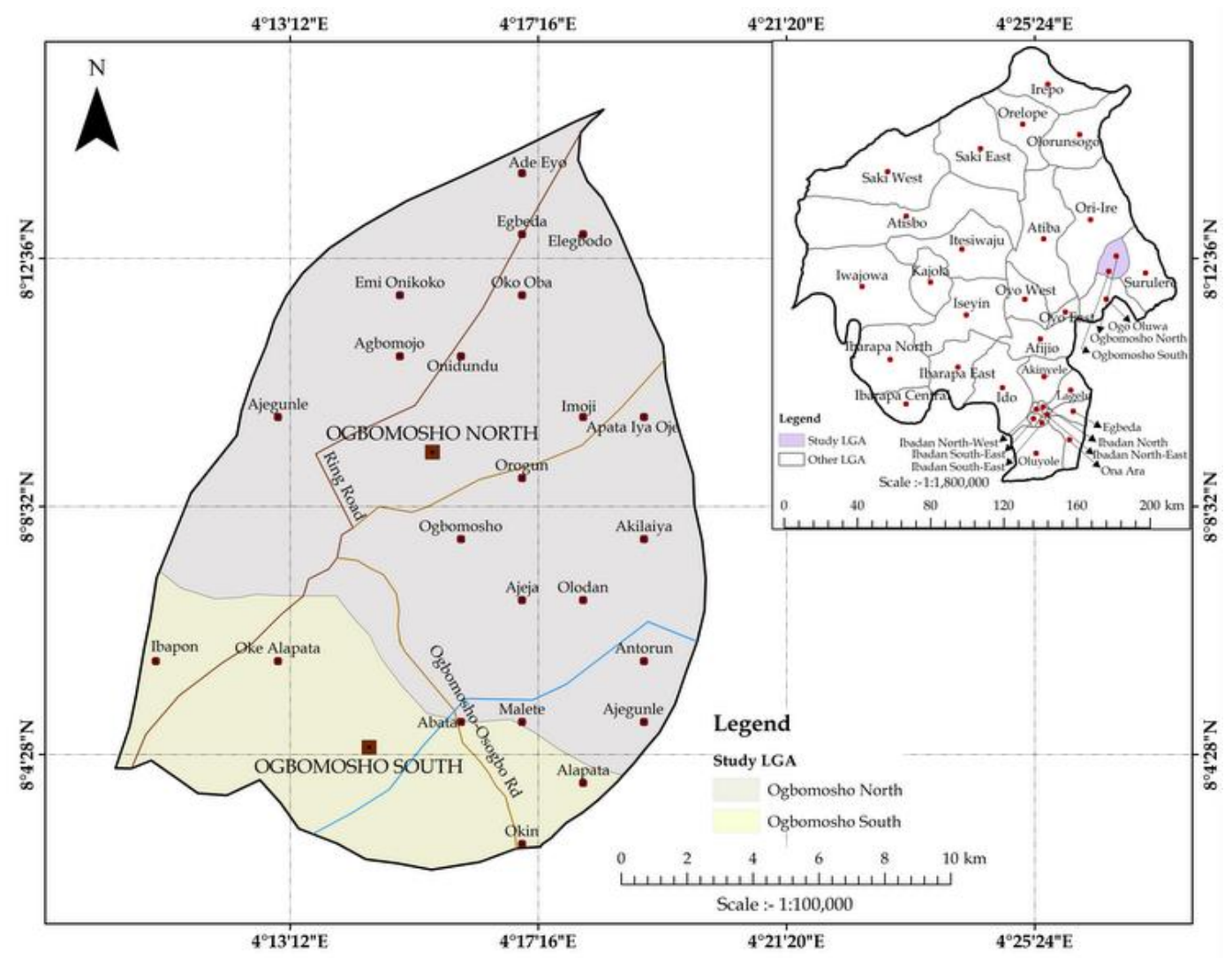

Figure 1. Map of Ogbomoso (Inset: Map of Oyo State Showing the Study Area) Source: Oyo State Ministry of Lands and Survey, 2016

The vegetation shares some characteristics with Guinea Savannah. The city of Ogbomoso comprises Ogbomoso North and Ogbomoso South inhabited by a significant proportion of the urban population in the state, which according to National Population Commission (2006) was put at 299,535. The people of Ogbomoso engage in various economics activities of which the major one is trading and farming.

\section{Materials and Methods}

Primary and secondary sources of data generation were employed to gather the needed data for the study. These include questionnaire administration and personal observation. In Ogbomosho, the 2014 voters registration put the total number of registered voters to be 56,693 and 81,792 (INEC, 2014) in Ogbomosho North and South respectively. Sample size was however determined with the: $\mathrm{N}=$ population size; $\mathrm{e}=$ level of significance $(0.05)$; thus $\mathrm{n}=400$ 
use of Yamane (1967:886)'s formula cited in Isreal (1992):

$$
n=\frac{\mathrm{N}}{1+\mathrm{N}(\mathrm{e}) 2}
$$

Where:

$\mathrm{n}=$ required sample size

$\mathrm{N}=$ population size

$\mathrm{e}=$ level of significance $(0.05)$

thus $n=400$

Hence, a total of 400 respondents were sampled with copies of questionnaire. Systematic random sampling technique was used to select every fifth building on the main road under dualization. Household heads were the target until a total of 400 house heads were sampled. Simple percentages, bar charts and likert rating scale (mean scores) were used to analyze the collected data to achieve stated objectives.

\section{Results and Discussion}

\section{Socio-demographic Characteristics of Respondents}

The study consists of $55.3 \%$ males as against $44.7 \%$ females (see table 1). This may be attributed to the fact that larger percentage of males drive vehicle than their female counterparts. This is similar to Adebayo (2005)'s report that larger percentage of males drive vehicle than the females. The result on table 1 further shows that $63.7 \%$ of the sampled respondents are married, $17.8 \%$ divorced, $12.5 \%$ single, $3.7 \%$ widowed, and $2.3 \%$ separated. This means that majority of the sampled respondents are married with family to move on daily basis either to work, market, school among others.

The age distribution as shown on table 1 reveals that majority $(95.8 \%)$ of the sampled respondents are within the age bracket of 18-48 years which is the economic active age group hence, the need to move to carry out their economic activities on daily basis. The level of education as depicted on Table 1 shows that $96.8 \%$ of the respondents are educated while only $3.2 \%$ do not have formal education. The occupation structure of the sampled respondents includes civil servants (36.5\%), artisans $(21.3 \%)$, self-employed (20.0\%), retirees (15.5\%), and students $(1.7 \%)$ (table1). The structure of the occupation depicts that the study area is fast urbanizing. This is in support of Harvey (2000) who submits that urbanization means heterogeneity of occupation. Income level of the

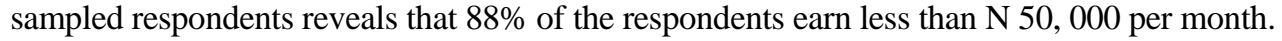

Table 1. Socio-demographic Characteristics of the Respondents

(Data sources: Authors' fieldwork 2016)

\begin{tabular}{|l|l|c|c|}
\hline Characteristics & Frequency & Percentage & Cumulative Percentage \\
\hline Sex & & & \\
Male & 221 & 55.3 & 55.3 \\
Female & 179 & 44.7 & 100.0 \\
$\quad$ Total & 400 & 100.0 & \\
Age of Respondents & & 16.0 & \\
18-27 years & 64 & 31.3 & 47.3 \\
28-37 years & 125 & 48.5 & 95.8 \\
38-47 years & 194 & 4.2 & 100.0 \\
48- and Above & 17 & 100.0 & \\
Total & 400 & 12.5 & 12.5 \\
Marital Status & & 63.7 & 76.2 \\
Married & 50 & 17.8 & 94.0 \\
Single & 225 & 3.7 & 97.7 \\
Divorced & 71 & 2.3 & 100.0 \\
Separated & 15 & 100.0 & \\
Divorced & 9 & & \\
Total & 400 & & \\
Level of Education & &
\end{tabular}




\begin{tabular}{|l|l|r|r|}
\hline No formal education & 44 & 11.0 & 11.0 \\
Primary Education & 56 & 14.0 & 25.0 \\
Secondary Education & 287 & 71.8 & 96.8 \\
Post Secondary Education & 13 & 3.2 & 100.0 \\
Total & 400 & 100.0 & \\
Occupation & 62 & 15.5 & 15.5 \\
Retired & 80 & 20.0 & 35.5 \\
Self Employed & 146 & 36.5 & 72.0 \\
Civil Servant & 85 & 21.3 & 93.3 \\
Artisan & 20 & 5.0 & 98.3 \\
Trader & 7 & 1.7 & 100.0 \\
Others & 400 & 100.0 & \\
Total & & 10.0 & 10.0 \\
Monthly Income & 40 & 49.8 & 59.8 \\
Below 10,000 & 199 & 28.2 & 88.0 \\
10,100-30,000 & 113 & 12.0 & 100.0 \\
30100-50,000 & 48 & 100.0 & \\
50100-Above & 400 & & \\
Total & & & \\
\hline
\end{tabular}

\section{Factors responsible for Road Dualization}

The study reveals that $35.5 \%$ of the respondents indicated traffic congestion as a result of increase in number of vehicles is the most pressing factor that necessitated the need for road dualization in Ogbomosho. This is in support of Gbadegesin and Aluko (2010) that rapid expansion of cities and improper planning (figure 2) has led to serious traffic congestion in most Nigerian cities.

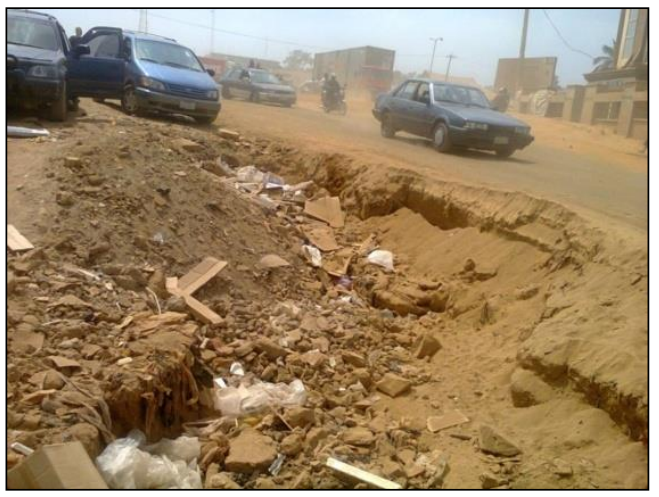

Figure 2. Taki Road and the Drainage System before the road dualization (Improper planning)

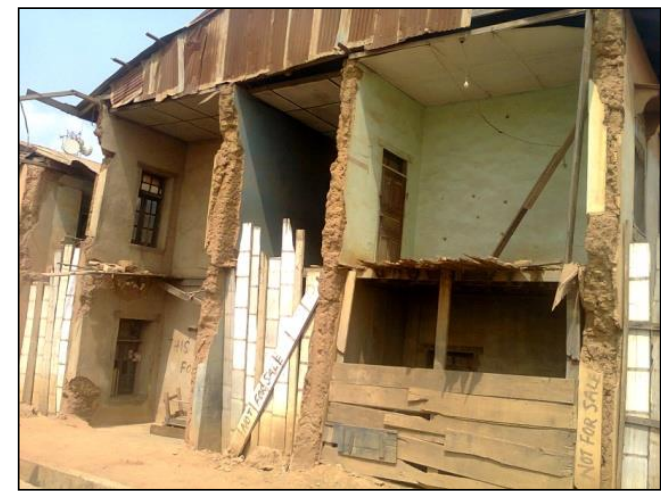

Figure 3. Demolished building for road expansion

Furthermore, other factors indicated by sampled respondents include: $22.8 \%$ indicated housing congestion, limited infrastructure was selected by $19.8 \%$ of the respondents, $19.0 \%$ also indicated decay of the available road facilities while others such as economic factors and modernization were indicated by only $3.0 \%$ of the sampled respondents. Hence, demolition of buildings (figure 3) for road expansion has led to increase in cost of shops and living house rentage, air, noise and water pollution and reduction of socio-cultural ties.

\section{Perception of the residents on the effect of road dualization}

From the study, the effects of road dualization on residents and the environment are both positive and negative. However, it was observed from the respondents that the positive impacts are more than the negative impacts. Table 2 depicts the perception of the residents on the effect of road dualization (figure 4) on them and the environment. From the table, larger percentage 
$(87.5 \%)$ strongly agrees that it has improved transportation network in the area with a mean value of 3.86. There is an improvement in transportation network in the sense that there is no traffic congestion again in the area. Also, $81.3 \%$ strongly agrees it has led to provision of street light (figure 5) with a mean value of 3.81 (table 2). This means the area has no street light before road dualization. Furthermore, $68.5 \%, 67.5 \%$ and $66.3 \%$ strongly agree that it has assisted in the quality of buildings (housing) with a mean value of 3.70 , beautification of the environment with a mean value of 3.63 and construction of drainages with a mean value of 3.63 respectively (see table 2 ).

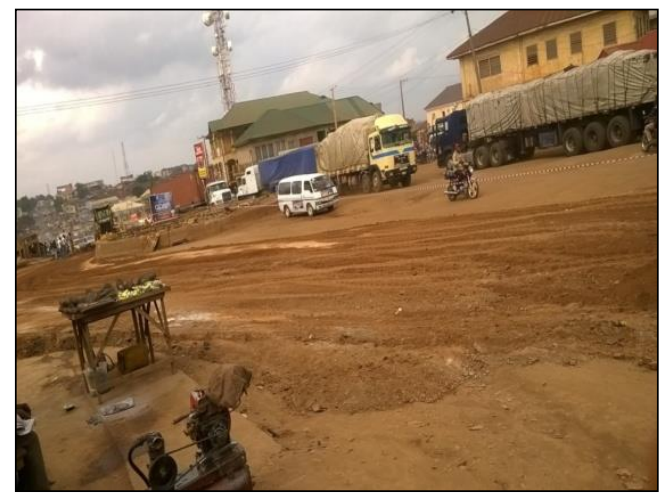

Figure 4. Road under construction

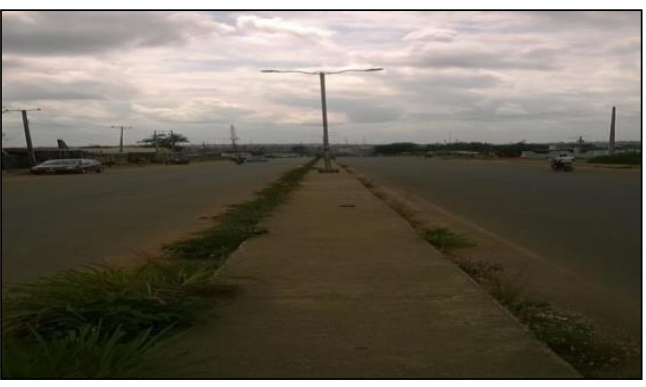

Figure 5. The dualized road with street light, drainage, and other facilities

Other factors perceived by respondents as effects of road dualization on the residents and environment include: Improved security $(x=3.52)$, Social ties $(x=3.32)$, increment in the cost of shop and house rentage (3.18), disruption of economic activities $(x=3.09)$, Homelessness $(x=2.98)$ and pollution through air, noise and water $(\mathrm{x}=2.81)$.

Table 2. Perception of the residents on the effect of road dualization (Data sources: Authors' fieldwork 2016)

\begin{tabular}{|c|c|c|c|c|c|c|c|}
\hline Perception & $\begin{array}{l}\text { Strongly } \\
\text { Agree }\end{array}$ & Agree & Disagree & $\begin{array}{l}\text { Strongly } \\
\text { disagree }\end{array}$ & Undecided & Mean & Rank \\
\hline Improved transportation network & $\begin{array}{c}350 \\
(87.5 \%)\end{array}$ & $\begin{array}{c}45 \\
(11.2 \%)\end{array}$ & $5(1.3 \%)$ & 0 & 0 & 3.86 & $1^{\text {st }}$ \\
\hline Provision of street light & $\begin{array}{c}325 \\
(81.3 \%)\end{array}$ & $\begin{array}{c}75 \\
(18.8 \%)\end{array}$ & 0 & 0 & 0 & 3.81 & $2^{\text {nd }}$ \\
\hline Improvement in housing quality & $\begin{array}{c}274 \\
(68.5 \%)\end{array}$ & $\begin{array}{c}113 \\
(28.2 \%)\end{array}$ & $13(3.3 \%)$ & 0 & 0 & 3.70 & $3^{\text {rd }}$ \\
\hline Beautification of the environment & $\begin{array}{c}270 \\
(67.5 \%)\end{array}$ & $\begin{array}{c}110 \\
(27.5 \%)\end{array}$ & $20(5.0 \%)$ & 0 & 0 & 3.63 & $4^{\text {th }}$ \\
\hline Construction of Drainages & $\begin{array}{c}265 \\
(66.3 \%) \\
\end{array}$ & $\begin{array}{c}130 \\
(32.5 \%) \\
\end{array}$ & 0 & 0 & $5(1.3 \%)$ & 3.63 & $5^{\text {th }}$ \\
\hline Improved security & $\begin{array}{c}265 \\
(66.3 \%)\end{array}$ & $\begin{array}{c}79 \\
(19.8 \%)\end{array}$ & $\begin{array}{c}56 \\
(14.0 \%)\end{array}$ & 0 & 0 & 3.52 & $6^{\text {th }}$ \\
\hline Social ties & $\begin{array}{c}230 \\
(57.5 \%)\end{array}$ & $\begin{array}{c}95 \\
(23.8 \%)\end{array}$ & $\begin{array}{c}50 \\
(12.5 \%)\end{array}$ & $23(5.8 \%)$ & $2(0.5 \%)$ & 3.32 & $7^{\text {th }}$ \\
\hline Increment in cost of Rentage & $\begin{array}{c}188 \\
(47.0 \%)\end{array}$ & $\begin{array}{c}109 \\
(27.3 \%)\end{array}$ & $\begin{array}{c}89 \\
(22.3 \%)\end{array}$ & $13(3.5 \%)$ & 0 & 3.18 & $8^{\text {th }}$ \\
\hline Disruption of Economic Activities & $\begin{array}{c}168 \\
(42.0 \%) \\
\end{array}$ & $\begin{array}{c}112 \\
(28.0 \%)\end{array}$ & $\begin{array}{c}109 \\
(27.3 \%)\end{array}$ & $11(2.8 \%)$ & 0 & 3.09 & $9^{\text {th }}$ \\
\hline Homelessness & $\begin{array}{c}107 \\
(26.8 \%)\end{array}$ & $\begin{array}{c}191 \\
(47.8 \%)\end{array}$ & $\begin{array}{c}87 \\
(21.8 \%)\end{array}$ & $15(3.8 \%)$ & 0 & 2.98 & $10^{\text {th }}$ \\
\hline Pollution (air, noise \& water) & $84(21.0)$ & $\begin{array}{c}184 \\
(46.0 \%)\end{array}$ & $\begin{array}{c}105 \\
(26.3 \%)\end{array}$ & $27(6.8 \%)$ & 0 & 2.81 & $11^{\text {th }}$ \\
\hline
\end{tabular}

Note: Strongly Agree $=4 ;$ Agree $=3 ;$ Disagree $=2 ;$ strongly disagree $=1 ;$ Undecided $=0$ 


\section{Facilities provided through road dualization project in Ogbomosho}

Various facilities were provided through road dualization in the study area. According to Aderamo (1990), road facilities are drainage, parking, road signs, street lights, traffic lights, pedestrain crossing among others. From the study, it was discovered that the following facilities were provided through the dualization project. These include: drainage facilities which help in reducing flood, parking facilities to control traffic congestion and road accidents, road signs which direct the road users especially the drivers, street light to provide illumination and security against different crimes like kidnapping, robbery and provision of traffic wardens within the segments of the roads.

\section{CONCLUSION}

The study has been able to establish the fact that road dualization is an activity that contributes to rapid urbanization and development process in the area. Although, in the course of road dualization, buildings consisting of houses and shops along the road to be dualized were demolished but the positive impacts outweighs the negative impacts. It can therefore be concluded that for any redevelopment scheme or project to be successful, the stakeholders (residents, government and contractor) have a great role to play. It is based on this study that the following recommendations were made: strategies should be developed by the government towards achieving comprehensive and more acceptable road dualization project that is sustainable. Public relation activities should be brought forward into urban and regional planning. This type of road dualization should be replicated in other urban areas experiencing heavy traffic congestion in Nigeria.

\section{REFERENCES}

Adebayo, P. (2005). A Geographical Analysis of Small-scale Industries in the City of Ogbomosho. Unpublished M. Sc Dissertation. Department of Geography, University of Ilorin, Nigeria.

Aderamo, A.J. (1990). Road Development and Urban Expansion: The Case Study of Ilorin, Nigeria. Unpublished Ph.D Thesis. Department of Geography, University of Ilorin, Nigeria.

Adetunji, M.A., Alabi, A.T., \& Oyeleye, O.I. (2018). Assessment of Built Environment Quality in Ogbomosho, Oyo State, Nigeria. International Journal of Physical and Human Geography, 6(2):1-10.

Couch, C. (1990). Urban renewal: Theory and practice. Macmillan International Higher Education.

Gbadegesin, J.T., \& Aluko, B.T. (2010). The programme of urban renewal for sustainable urban development in Nigeria: issues and challenges. Pakistan Journal of Social Sciences, 7(3), 244-253.

Harvey, R. (2000). Urban Land Economics, 5 ${ }^{\text {th }}$ ediction. Palgrave Publishers Ltd pp $270-275$. https://www.amazon.com>urban-land-http://en.climatedata.org/location/399286/

Herman, G.V. (2009a). Omul şi modificările antropice din Câmpia Someşului [The man and anthropogenic changes in Somes Plain]. Editura Universității din Oradea, p. 227 p., ISBN 978-973-759-981-0, Oradea.

Herman, G.V. (2009b), The Impact of Road Infrastructure on the Natural Someş Plain. Analele Universităţii din Oradea, Seria Geografie, 19, pp. 195-200.

Herman, G.V., Deac, A.L., Ciobotaru, A.M., Andronache, I.C., Loghin, V., \& Ilie, A.M. (2017). The role of tourism in local economy development. Bihor County case study. Urbanism. Arhitectura. Constructii [Urbanism Architecture Constructions], 8(3), 265-274.

Herman, G.V., Peptenatu, D., Grama, V., \& Pintilii, R.D. (2018). Tourism and Local Development. Study Case: Băile Felix-Băile 1 Mai Tourism System, Bihor County, Romania. Annals of the University of Oradea, Geography Series/Analele Universitatii din Oradea, Seria Geografie, 28(1): 131-137.

Ilieş, D.C., Herman, G.V., Dehoorne, O., \& Măduţa, F. (2013). The role of the importance of cyclotourism in the development of the Oradea Metropolitan area (Romania). GeoJournal of Tourism and Geosites, 12(2): 101-110.

Isreal, G.D. (1992). Determining Sample Size Agricultural Education and Communication Department, University of Florida, IIFAS Extension, PEOD6. (Reviewed 2013).

Kabiru, K., Mathew, A., \& Isaac, A.A. (2014). Unmet Social needs and teenage pregnancy in Ogbomosho, South-western Nigeria. African Health Sciences, 14(4): 956-966.

Kuponiyi, E., Ogunlade, F. A., \& Oyetoro, J. O. (2010). Farmers Perception of Impact of Climate Changes on Food Crop Production in Ogbomosho Agricultural Zone of Oyo State, Nigeria. Global Journal of Human-Social Science Research, 10(7).

Layard, A., Davoudi, S., \& Batty, S. (2012). Planning for a Sustainable Future. Taylor and Francis Group. London and New York. 
Miller, J.M. (1959). Life for Cities around the World. International Handbook on Urban Renewal. Books International, New York.

National Population Commission (2006). Population Census of the Federal Republic of Nigeria, Official Gazette, Abuja, Nigeria.

Osuide, S. O., \& Dimuna, K. O. (2005). Effects of population growth on urbanization and the environment in Nigeria. In Proceeding of Year 2000 National Seminar on Population, Growth, Architecture and the Environment. Rasjel Publishers, Ekpoma.

Oyesiku, K. (2011). Development before town planning cause of flooding in Nigeria. www.vanguardngr.com, Retrieved on July, 2011.

Yamane, T. (1967). Statistics, An Introductory Analysis, $2^{\text {nd }}$ Ed, New York: Harper and Row.

*** (2004). NUDP (National Urban Development Policy) The Draft National Urban Development Policy.

*** (2016). Oyo State Ministry of Land and Survey.

http://en.climatedata.org/location/399286/ (accessed at: 01.09.2018)

Submitted:

April 29, 2018
Revised:

Octomber 20, 2018
Accepted and published online January 21, 2018 